\title{
101 years of the psychiatric ward and the psychiatric hospital in Radom (1912-2013)
}

\begin{abstract}
Introduction. In the context of ongoing changes in the organization of psychiatric care announced by the National Mental Health Programme for 2011-2015, changes in psychiatric care in the Radom region over the last hundred years have been presented.

Aim. Presentation of the activities of institutional psychiatric care in the long term and to indicate the necessity of functioning of the psychiatric inpatient departments.

Material and methods. Analysis of documents, mainly statistical and reports concerning the activities of mental health care in Radom.

Conclusions. Psychiatric Hospital in Radom is one of the largest hospitals in Poland. It supports the area of the former province of Radom inhabited by more than half a million people and has a rich human resources potential and interesting infrastructure. However, the unceasing progress in medicine forces continuous investment in medical staff in order to increase knowledge and improve skills that are necessary to maintain a high quality of provided medical services and the needs of teaching and research. The increase in the number of admissions of patients in the last decade (2001-2010) compared to the previous decade (1991-2000) was 27\%, while the number of admissions of patients to the psychiatric wards has increased about $43.5 \%$ and was the highest in the history of the hospital. Dynamics of admissions with simultaneously reduced length of hospitalization requires further, in-depth analysis. The creation of the Chronic Psychiatric Medical Home Care in 2001 with 100 beds and its extension in just a few years has increased the number of beds to 235. Moving the care towards psychiatric long-term care demonstrates the growing needs in this area and the failure of the system to provide community psychiatric care in the Radom region.
\end{abstract}

Keywords: psychiatric hospital, mental disorders, hospitalization, history.

DOI: $10.12923 /$ j.0044-2011/123-4/a.14

\section{INTRODUCTION}

The Independent Regional Public Psychiatric Hospital named after Dr. Barbara Borzym in Radom is one of the largest and oldest psychiatric hospitals in Poland, which just began 102 years of its activity. However, it has not been yet presented chronologically. The continuum of the institutional psychiatric care in Radom is as follows.

Mentally ill, waiting for examination in the Governorate Faculty of Medicine, were held in two rooms, specially designed for them, of the hospital of St. Kazimierz in Radom [1]. The hospital in Radom would send the mentally ill to the hospital in Tworki, where four seats were reserved for the Radom Governorate [2]. In 1903, at the initiative of the doctor Feliks Bijejko (born on 15.01.1843, died on 19.01.1924, Warsaw University 1873) the coat of arms Jastrzębiec the Private Association for Care of the Mentally and Nervously Ill was established in the Radom Governorate $[3,4]$. The Board of the Association through their own outlays arranged in 1912 the Almshouse for 17 residents, and in 1916, there were already 22 people "incurably insane" in it [5]. Piątkowski confirms that at the end of 1919 Hospital for the Mentally Ill functioned as one of seven hospitals in Radom, maintained by Association for Care of the Mentally and Nervously Ill, but in a building belonging to the city [6].

Until 1930, the hospital was under the supervision of the Association, and the management of the almshouse - the hospital was taken over completely by the city and patients were moved to the rooms of the thirteenth century Church of St. Wacław. Medical care was held by Dr. Włodzimierz Parniewski (son of Piotr, born on 08.01.1893, died in 1987, Uniwersity in Kiev 1917), and from 01.09.1939 by Jerzy Borysowicz MD (son of Franciszek, born on 28.04.1903, died on 05.06.1980r., University in Vilnius named Stefan Batory 1929), a specialist neurologist and psychiatrist. Thanks to the efforts of Dr. Borysowicz, on 01.04.1945 the almshouse as a Psychiatric Ward was included in the structure of the Municipal Hospital of St. Kazimierz (then the name of Dr. Tytus Chałubiński). It became the first center for psychiatric treatment in the region Kielce - Radom, 
extremely needed because "the Kielce region since time immemorial had been completely neglected in psychiatric terms" [7]. In Kielce, there was only the Shelter for Mentally Disabled, which was founded in 1936 with 30 bed base, increased during the occupation to 60 beds. The first psychiatrist Stefan Dembowski (son of Witold, born on 22.02.1887, died in 1970, Warsaw University 1924) began work only in 1948, and the shelter was included in the structure of the Regional Hospital in Kielce as a 80-bed psychiatric ward in 1951, that was six years later.

In October 1947, the Psychiatric Ward in Radom had 46 beds, and patient care was exercised by one doctor (Dr. J. Borysowicz), one nurse, seven attendants, a cook and seamstress [8]. Number of beds, even after increasing to 76 , was still insufficient. According to statistics for the year 1960, contained in the work of Bilikiewicz and Gallus [7] 345 patients were admitted to the ward, 407 were treated, the number of man-days was 24,741, and 9 people died (mortality rate for all treatment amounted to 2.2). Dr. Borysowicz together with Dr. Barbara Borzym (daughter of Stanisław and Maria nee Ziółkowska, born on 18.01.1926, died on 15.10.1990, Medical Academy in Warsaw 1952) constantly appealed to the central government in Warsaw for an increase in the number of beds for the mentally ill.

It was only in 1958 when The Ministry of Health committed to build National Psychiatric Hospital in the Krychnowice. According to data from the Department of Prevention and Treatment of the Ministry of Health and Welfare as of February 1961 in 5-year plan (1961-1966) was provided "the New psychiatric hospital in the Krychnowice" for 246 beds [7]. The Presidium of Municipal National Council in Radom, on 8.10.1958, agreed to locate the Psychiatric Hospital in the divided estate of Krychnowice.

On 31.12.1964 patients were transferred from the psychiatric ward of the city hospital to the first pavilion [9], and the grand opening of the National Hospital for the Nervously and Mentally Ill in the Krychnowice near Radom took place on 05.29.1965.

In subsequent years, there were created the following pavilions: a two-storey pavilion III in the amount of 190 beds, a pavilion for children and adolescents in the amount of 82 beds (1969), pavilion IV - rehabilitation for the chronically mentally ill (1970), somato-diagnostic pavilion (1970), in which the emergency room was situated, a psychosomatic ward in the amount of 46 beds. There were also workrooms: $\mathrm{X}$-ray, laboratory, workrooms of therapeutic rehabilitation, dental, ophthalmological and pharmacy (1970). In February 1971, a neurological ward (64 beds) and neuroses ( 23 beds) were opened. In March 1972, a 45 bed-ward of treatment for alcohol addiction was opened, which was located in pavilion IV.

National Hospital for the Nervously and Mentally III in the Krychnowice near Radom functioned until the September 1972. In the same year, the hospital was transferred from the central budget to the budget of the field. Resolution No. 98/1061/72 the Presidium of the Provincial National Council in Kielce, on September 4, 1972 on the change in the name of the National Hospital for the Nervously and Mentally Ill in the Krychnowice near Radom made changes to the name of the Regional Specialized Hospital for the Nervously and Mentally Ill in the Krychnowice near Radom commune Kowala, district of Radom, province of Kielce, subjected directly to the Department of Health and Social Welfare of The Presidium of the Provincial National Council in Kielce.

In 1972 the hospital had 1,036 actual beds on the following wards:

- 4 Psychiatric Wards for Women;

- 4 Psychiatric Wards for Men;

- Psychiatric Ward for Children and Adolescents;

- Neuroses Ward;

- Psychosomatic Ward;

- Neurological Ward;

- Alcohol Treatment Ward;

- Emergency Room.

Regional Specialist Hospital for the Nervously and Mentally Ill was characterized by a constant readiness to admit the patients and provide the daily, versatile and qualified medical care involving the observation, diagnosis, nurturing and treatment.

In the years 1965-1974 the hospital covered the area of the following counties: Radom, Białobrzegi, Końskie, Kozienice, Lipsko, Opoczno, Przysucha, cities: Radom, Starachowice, Szydłowiec, Zwolen, Rawa Mazowiecka, Tomaszów Mazowiecki with over a million of residents.

The report for the year 1973 to the Consultant of Kielce Province (to which Radom belonged) Dr. Boguchwał Winid (born on 15.05.1925, in Poznań, died on 04.04.2003, Medical Academy in Kraków 1951), then Deputy of Director for Treatment Bogdan Kowal (son of Aleksy, born on 02.01.1929, in Kołaczkowice, died on 06.09.1996, in Radom, Medical Acedemy) stated: "Six psychiatric wards with a total amount of 572 beds provide services for the area inhabited by more than 1 million population (mostly urban). The other beds are in neurological ward, psychiatric ward for children and adolescents, psychosomatic ward, neuroses ward and psychiatric rehabilitation ward" [10].

By a decision of 15.03.1983, amending the boundaries of the city of Radom, Regional Mental Health Care Hospital in the Krychnowice was incorporated in the city boundaries, giving the address: Krychnowicka 1 Street, Radom,which is still valid.

On 15.09 .1983 , the newly built pavilion of alcohol addiction treatment was opened ( 62 beds), which increased the number of beds to 1,098 .

Twenty years after the inception, psychiatric hospital still provided medical services for the population living in the province of Radom and in part the province of Kielce and Piotrków in a number of 1,032,308. The structure of beds presented as follows:

- 926 beds of psychiatric profile

- 62 beds for the alcohol treatment

- 64 neurological beds

- 46 internal medicine beds [11].

The ratio of psychiatric profile beds per 10 thousand population - for the entire region, was in $1985-9.0$, and for the Radom Province - 12.7 (in 1975 - 12.9, in $1980-12.5$ ). The number of alcohol treatment beds: for the whole region was in $1985-0.6$, and for the Radom Province - 0.85 [11]. 
In 1985 in Regional Mental Health Care Hospital there were employed 45 physicians (16 physicians with first degree of specialization, 23 with second degree, in the total number there were 24 specialists in psychiatry), 3 dentists, 4 pharmacists, 283 persons belonging to the average medical staff, including the 237 nurses [11].

Over the decades, unfortunately the population for which the hospital has rendered its services has not been reduced, and even increased to 1,066 million (as of 31.12.1995), and the district of psychiatric ward for children and adolescents included the Provinces of Radom, Kielce, Piotrkow, Tarnobrzeg.

By the order of the Governor of Radom No. 26 of 20.08.1998, Regional Mental Health Care Hospital was transformed into Independent Public Healthcare Hospital named after Dr. Barbara Borzym, entered in the register of independent public health care units, ceased to be a budget unit and acquired autonomy and legal personality. These changes were necessary to conclude contracts on the health benefits with Health Maintenance Organization. The founding authority was still Governor of Radom.

As a result of changes in the administrative division of Poland, Radom became a part of the Mazowieckie Province and from 01.01.1999 the Self-Government of Mazowieckie Region has been the founding authority of the Hospital. It continued to develop in the subsequent years. With expanding activities in the provision of the health benefits for people with psychiatric problems and alcohol addiction, the name of the hospital had to be changed to the Independent Regional Public Psychiatric Hospital named after Dr. Barbara Borzym in Radom, which has been functioning to this day. Already at this age, there were created: Chronic Psychiatric Medical Home Care (01.09.2001), Neurological Ward, Rehabilitation Ward (from the transformation of the Neurological Ward 10.09.2001) Day Care Ward for Children and Adolescents (01.02.2002 with the closure of 30.10.2012), Treatment and Therapy of Psychoactive Substances Abuse Ward (27.06.2002).

On 01.10.2013 the institution had 510 beds, at the following wards for men and women:

- 5 Psychiatric for Adults;

- Psychiatric for Chronically Ill People;

- Psychosomatic;

- Neurotic Disorders Treatment;

- Treatment of Alcohol Withdrawal Syndromes with the sub-ward of Treatment of Withdrawal Syndromes after the Psychoactive Substances;

- Neurological Rehabilitation and

- a modern, expanded in 2012 Chronic Psychiatric Medical Home Care (235 beds).

The Independent Regional Public Psychiatric Hospital also includes Specialist Center of Ambulatory Care containing in its structure the following outpatients' clinic:

- Mental Health for Adults;

- For Children with Autism;

- Neurological;

- Neurological Rehabilitation;

- Alcohol Addiction Therapy and co-addicted.
Currently Independent Regional Public Psychiatric Hospital is a complex specialist treatment - psychiatric, alcohol and drug abuse and rehabilitation unit, providing a full range of health benefits in this area. Average number of patients admitted during the year is 7000 (Figure 1). Its range includes the city of Radom, and the southern part of the Mazowieckie Province. Other hospitals of similar activities are located in a distance of about 70-100 km. (Hospital in Morawica in the Świętokrzyskie Province and a hospital in Tworki near Warsaw - Mazowieckie Province). For exceptional medical benefits to the population of such an extensive area, should be included the fact of giving them in the Wards of Neurotic Disorders and Psychosomatic (Figure 2). Steady increase in admissions of patients to these wards has been observed. On the other hand, the liquidation of the Psychiatric Ward for Children and Adolescents has caused the gap, which has so far failed to be fulfilled.

The hospital also meets an important role in education in the field of psychiatry, clinical psychology and psychiatric and neurological rehabilitation for higher and middle medical staff in the Radom region. Over the years, a number of publications have been published, especially in the field of adolescence psychiatry. The founder and longtime head of the psychiatric ward for children and adolescents, Dr. Jerzy Szafranek (son of Aleksy, born on 20.02.1933, in Gleśno, died on 13.12.2005 in Radom, Medical Academy in Gdańsk 1957), was the initiator and main organizer of the $3^{\text {rd }}$ National Conference of Child and Adolescent Psychiatrists in 1979. Throughout its activities, the hospital proved

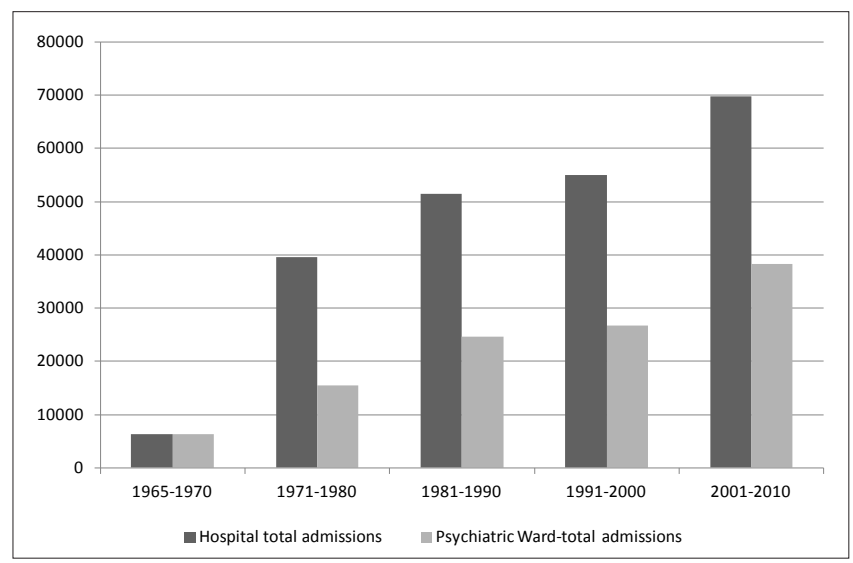

FIGURE 1. Number of admissions to psychiatric wards in relation to the total admission.

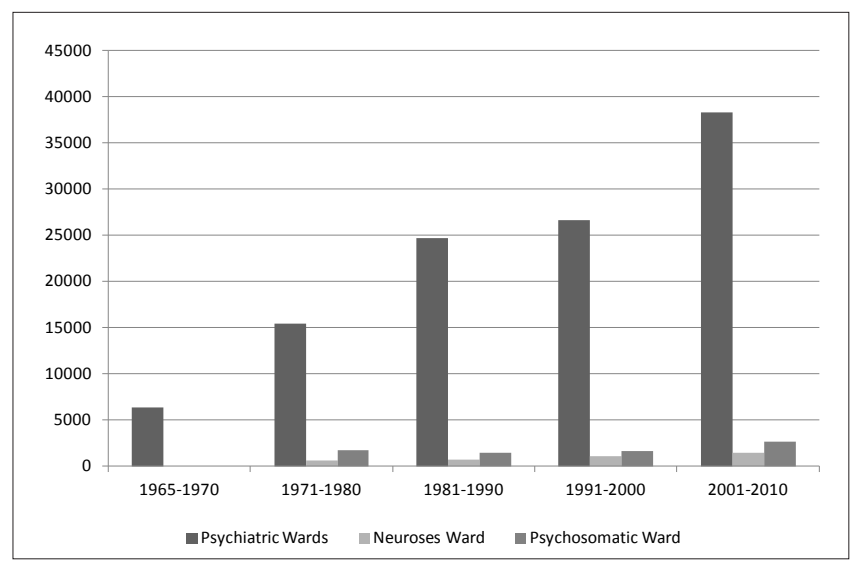

FIGURE 2. Number of admissions in the individual decades in selected wards. 
its important role in the region. It became also a living monument of the people who created it, filled with work and developed it - fulfilling their visions and goals. Honoring their activities is giving to the Hospital the name of Dr. Barbara Borzym on 19.08.1991 [12] and giving a name of Dr. Bogdan Kowal to the Chronic Psychiatric Medical Home Care.

\section{CONCLUSIONS}

1. Psychiatric Hospital in Radom is one of the largest hospitals in Poland. It supports the area of the former province of Radom inhabited by more than half a million people and has a rich human resources potential and interesting infrastructure. However, the unceasing progress in medicine forces continuous investment in medical staff in order to increase knowledge and improve skills that are necessary to maintain a high quality of provided medical services and the needs of teaching and research.

2. The increase in the number of admissions of patients in the last decade (2001-2010) compared to the previous decade (1991-2000) was 27\%, while the number of admissions of patients to the psychiatric wards has increased about $43.5 \%$ and was the highest in the history of the hospital. Dynamics of admissions with simultaneously reduced length of hospitalization requires further, in-depth analysis.

3. The creation of the Chronic Psychiatric Medical Home Care in 2001 with 100 beds and its extension in just a few years has increased the number of beds to 235. Moving the care towards psychiatric long-term care demonstrates the growing needs in this area and the failure of the system to provide community psychiatric care in the Radom region.

\section{REFERENCES}

1. Обзор Радомской губернии за 1873 год, Радом; 1874.

2. Kisiel H. Zdrowotność i Służba Zdrowia. In: S. Witkowski (ed). Dzieje miasta w XIX i XX w. Warszawa: PWN; 1985. p.141-4.

3. Akta miasta Radomia. Sygn. 8251, bez paginacji. Archiwum Państwowe w Radomiu.

4. Fidler H. Stan szpitalnictwa oraz ruch chorych w szpitalach ziemi radomskiej w latach 1908-1911 (włącznie). Warszawa; 1914.

5. Biejejkowa S. Towarzystwo Opieki nad Umysłowo i Nerwowo Chorymi w Radomiu. In: Kalendarz Radomski na rok zwyczajny 1917. Radom; 1916.

6. Piątkowski S. Początki działalności Związku Specjalnego dla Utrzymania i Prowadzenia Szpitali w Radomiu (1920-1923). Radom Rocz Lek. 2000;5:193-200.

7. Bilikiewicz T, Gallus J. Psychiatria polska na tle dziejowym. Warszawa: PZWL; 1962.

8. Tochterman A. O szpitalach i lekarzach radomskich (oprac. i przypisami opatrzył dr med. R. Wiraszka). Radom Rocz Lek. 2000;V:117-89.

9. Kasperski E, Lis Z, Maj A, Zapała D. Z dziejów radomskiej służby zdrowia 1944-1984. Radom; 1984.

10. Sprawozdania statystyczne z działalności szpitala - 1973. Archiwum SWPZZPOZ; 1973.

11. Informator statystyczny służby zdrowia woj. Radomskiego 1985. Wojewódzki Zespół Metodyczny Opieki Zdrowotnej i Pomocy Społecznej w Radomiu. Radom; 1986.

12. Zarządzenie Nr 96/91 Wojewody Radomskiego z dnia 19 sierpnia 1991r. uzupełniające Statut Wojewódzkiego Zespołu Psychiatrycznej Opieki Zdrowotnej.

Informacje o Autorce

Mgr Bożena KosıńsKa - Samodzielny Wojewódzki Publiczny Zespół Zakładów Psychiatrycznej Opieki Zdrowotnej im. dr Barbary Borzym w Radomiu.

\section{Corresponding Author}

Bożena Kosińska

ul. Krychnowicka 1, 26-607 Radom

tel. (48) 332-45-56; 509-037-118

E-mail: bozko@vp.pl 